\title{
Ideology-Critique with the Conceptual Hinterland of a Theory of the Ideological
}

\section{Jan Rehmann}

Union Theological Seminary, USA, and Free University Berlin, Germany

\begin{abstract}
The 'ideology-theoretical turn' of the late 1970s and 1980s claimed a re-foundation of Marxist research into ideology, which was stuck in several respects. Its attempt to overcome the traditional fixation on a criticism of 'false' consciousness is still valid. It led, however, in particular in the tradition of the Althusser School, to an over-general notion of ideology that repressed the radical and critical impulses of Marx and Engels' concept of ideology. Going deliberately against the grain of a predominant tendency in secondary literature, which places Marx/Engels' and Gramsci's concepts of ideology on opposite poles of the spectrum, the essay shows that the strength of the respective approaches lies in their particular combination of ideology-critique and ideology-theory. The dichotomy of these strands is misguided and counterproductive and needs to be overcome by the renewal of an ideology-critique which is informed and backed up by a materialist theory of the ideological.
\end{abstract}

\section{Keywords}

Althusser, common sense, compromise formation, good sense, Gramsci, hegemony, ideologycritique, ideology-theory, neoliberalism, philosophy of praxis

\section{Introduction}

It was mainly the failures of the ' 68 movements and the ensuing 'crisis of Marxism' which provoked the emergence of ideology theories in the 1970s and 1980s. Their foundational claim was to grasp the inner stability of bourgeois society and its state, which could obviously not be sufficiently explained by violence, manipulation or 'false consciousness'. How to identify the mechanisms that cause subaltern classes to 'voluntary' and often passionately enact their submission to a system of domination that contradicts their vital interests? The question is obviously still relevant in the early 21 st century, which sees a neoliberal high-tech capitalism still capable of maintaining a hegemonic stability, even in the midst of its severe economic crises. 
Having participated myself in one of the ideology-theoretical 'schools', the Projekt Ideologietheorie (PIT), a research group led by Wolfgang Fritz Haug, the editor-in-chief of the review Das Argument and of the renown Historical Critical Dictionary of Marxism (HKWM), I would like to take a step back and look at a specific bifurcation which revealed itself as problematic: since the history of theories often moves through pendulum swings, the traditions of ideologycritique and of ideology-theory have developed separately and often against each other. I will try to demonstrate that the ideology-theoretical claim to overcome the traditional fixation on a criticism of 'false' consciousness was productive and is still valid, but that it led, in particular in the tradition of the Althusser School, to an over-general notion of ideology that repressed the radical and critical impulses of Marx and Engels' concept of ideology. Based on two allegedly opposite examples, namely Marx and Engels' critical concept of ideology and Gramsci's theory of hegemony, I will show that the demarcations between ideology-critique and ideology-theory are not as clear-cut as widely assumed and that the strength of the respective approaches lies in their particular combination of ideology-critique and ideology-theory. I will conclude that the separation and dichotomy of these strands is misguided and counterproductive and needs to be overcome in turn by the renewal of an ideology-critique which is informed and backed up by a materialist theory of the ideological.

\section{The Ideology-Theoretical Turn: A Departure from Ideology- Critique?}

The term 'ideology theory' emerged in the 1970s and 1980s, first in connection with Louis Althusser in France, then of Stuart Hall in the UK and the Berlin Projekt Ideologietheorie (PIT). The common claim was to enable a re-foundation of Marxist research into ideology, which was stuck in several respects. Ideology-theory thus marked a double distinction: first, from a widespread 'economism', which reduced ideology to a mere epiphenomenon of economic class interests and thus missed the relative autonomy of the ideological; second, from a traditional ideology-critique, which understood the ideological merely as a 'false' and 'inverted' consciousness that was to be criticized from the standpoint of a 'scientific world view'.

The objections to such an ideology-critique can be summarized in three points. First, the criticism of 'false consciousness' had not yet reached the social scientific level in that it overlooked the material existence of the ideological, its reality as an arrangement of apparatuses, intellectuals, rituals, and forms of praxis. Althusser tried to conceptualize this arrangement with his theory of 'ideological state apparatuses', which in turn referred back to Gramsci's concept of 'hegemonic apparatuses'. Secondly, it tended to miss, by its fixation with phenomena of consciousness, the unconscious functioning of ideological forms and practices, their formatting of subjectivities and their anchorage in bodily dispositions and attitudes of 'habitus' (Bourdieu). The notion of 'falseness' is furthermore a highly generalizing and potentially totalizing notion, which dissimulates the contradictory composition of ideologies; and finally, the endeavor to 'refute' ideologies risks drawing attention away from the main ideology-theoretical task, which is to grasp their efficacy in subjecting minds, bodies, and 'hearts'. It seduces critical intellectuals into tearing down oppositional or competing world views without carefully paying attention to and working on the realistic elements within ideologies and common sense. This applies, for example, to 'family values', which are, despite the obvious hypocrisy and bigotry of many of their conservative proponents, not simply 'false', but represent, in whatever displaced or distorted forms, longings for solidarity, closeness, and reliability in a torn world, and this not least among the impoverished and marginalized, whose family lives have been unhinged and destabilized. According to Stuart Hall (1988: 46), the most important question regarding an 'organic' connective ideology is 'not what is false about it but what about it is true', i.e. not in terms of a universal truth but rather of what 'makes good sense'. 
A careful understanding of ideology's appeal is a necessary prerequisite for developing an efficacious critique which, according to the famous description of Ernst Bloch, is able to 'release' its appealing elements capable of transformation and to 'remount them for functioning in a different connection' (1990: 113).

Bloch's proposal should caution us, however, that the notions of 'critique' and thereby 'ideologycritique' can be utilized in quite different ways. In the Contribution to the Critique of Hegel's Philosophy of Right (1843), the young Marx had opposed a 'vulgar', 'dogmatic' criticism, which 'fights with its subject-matter', and 'true philosophical criticism', which does not only show the contradictions of phenomena as existing but 'explains them, $[\ldots]$ comprehends their genesis, their necessity' (MECW 3: 91). Critique in a Marxian sense, in particular as developed in his Critique of Political Economy, does not mean the rejection of a phenomenon 'from the outside', but rather the historical-critical reconstruction of its emergence, inner composition and transitory necessity. A critique in the sense of a 'determinate negation', which is able to identify and to 'set free elements of the new society with which [...] bourgeois society itself is pregnant' (MECW 22: 335), would thus coincide with the methodological claim of ideology-theories.

This indicates that the demarcations between ideology-theory and ideology-critique are not as fixed as it first seemed. At a closer look, most of the approaches usually described as 'ideologycritical' (e.g. from Lukàcs to Horkheimer, Adorno and Marcuse) also try to explain the conditions of emergence and efficacy of ideologies. At the same time, ideology-theories also contain a component of critique which, however, shifts from the traditional paradigm of a true-false dichotomy to the analytical distinction between domination and emancipatory agency. In this vein, the Projekt Ideologietheorie (PIT) proposes to differentiate between an ideological 'socialization from above' and dimensions of 'horizontal' socialization in the sense of a consensual control of the conditions of social life, which takes place whenever the common is re-claimed and re-appropriated from below. It will be shown with the example of Althusser that an ideology-theory proclaiming to do without an ideology-critical perspective runs the risk of being transformed back into a functionalist theory of legitimacy.

In a first step, I'd like to go back to Marx and Engels, whose critical concept of ideology was considered by many theorists as a case in point for a hopelessly antiquated type of ideologycritique. I will try to show that this is a one-sided and ultimately fallacious interpretation that fails to differentiate between different layers of their deliberations.

\section{Marx and Engels: The Material Dispositive behind the Camera Obscura}

The critique of ideology as necessarily inverted consciousness could refer to numerous formulations in which Marx and Engels (for example, in relation to religion) spoke of 'inverted worldconsciousness', an 'independent kingdom in the clouds', a 'distorted conception', a 'standing on its head', and so forth. ${ }^{1}$ Ideology was accomplished by the thinker with a 'false consciousness' who missed the real motives impelling him; 'otherwise', noted the late Engels, 'it would not be an ideological process' (MECW 50: 164). According to The German Ideology, ideologists 'inevitably put the thing upside-down and regard their ideology both as the creative force and as the aim of all social relations, whereas it is only an expression and symptom of these relations' (MECW 5: 420).

Marx and Engels summarized the different descriptions of 'distortion' and 'inversion' in the image of a camera obscura: 'If in all ideology men and their circumstances appear upside-down as in a camera obscura, this phenomenon arises just as much from their historical life-process as the inversion of objects on the retina does from their physical life-process' (MECW 5: 36). In order to disprove the idealistic inversions of 'German philosophy', which 'descends from heaven to earth', 
they claimed not to start from 'what men say, imagine, conceive' but rather from 'men in the flesh': 'Setting out from real, active men, and on the basis of their real life-process', they attempted to demonstrate 'the development of the ideological reflexes and echoes of this life-process. [...] It is not consciousness that determines life, but life that determines consciousness' (MECW 5: 36ff.).

It was primarily these (and similar) formulations that became the target of the ideologytheoretical turn. Althusser argued that The German Ideology understood ideology as mere 'form of consciousness' (forme-conscience), 'in a plainly positivist context [...] as a pure illusion, a pure dream, i.e. as nothingness [...], empty and vain' (Althusser, 1994: 496; 2001: 108). According to Stuart Hall, terms like 'false consciousness' or 'ideological distortion' assumed that the masses were the 'dupes of history' whereas 'we', the critical intellectuals, were supposedly able to live without illusion (1988: 44). He explained this with an epistemological fallacy, namely an 'empiricist relation of the subject to knowledge', according to which 'the real world indelibly imprints its meanings and interests directly into our consciousness' (1988: 44). For Raymond Williams, it was an 'objectivist fantasy' to believe that 'real' life conditions could be known 'independently of language [...] and of its records', because it would be a fallacious assumption that there was 'first material social life and then, at some temporal or spatial distance, consciousness and "its" products', which were, in reality, 'always [...] parts of the material social process itself' (Williams, 1977: 60-1). Terry Eagleton believed to have discovered that Marx and Engels were guilty of a 'naive sensuous empiricism which fails to grasp that there is no "real life-process" without interpretation': 'What distinguishes the human animal is that it moves in a world of meaning; and these meanings are constitutive of its activities, not secondary to them'. He drew the conclusion that Marx and Engels' camera obscura metaphor was unable to grasp the active and dynamic nature of human consciousness and instead reduced it to a device 'passively recording objects in the external world' (Eagleton, 1991: 73-6).

At this point, it becomes questionable whether these criticisms really hit the mark of Marx and Engels' approach. Around the same time that Marx and Engels were writing The German Ideology (1845-6), Marx published his Theses on Feuerbach (1845), whose first thesis criticized that 'all previous materialism' had conceived of reality and of sensuousness 'only in the form of the object, or of contemplation, but not as sensuous human activity, practice, not subjectively'. In contrast to such an objectivist 'previous materialism', Marx highlighted the achievement of idealism as having set forth the 'active side', however only 'abstractly', since it 'does not know real, sensuous activity as such' (MECW 5: 3). Given the fact that the Theses on Feuerbach announced the supersession of an 'old materialism' by a 'new' one (MECW 5: 5), which started from subjective practice, it would be astonishing if The German Ideology assumed a 'passive' reflection of the exterior world by consciousness, thus falling back to the position that Marx had just denounced.

Let us look at the key passage, in which The German Ideology tried to counter the philosophy of conscience by developing five aspects of social activity. Against the evolutionist interpretation put forward by Williams and Eagleton (first 'real life', then meaning), Marx and Engels emphasized that these aspects 'are not of course to be taken as [...] different stages, but just as [...] "moments", which have existed simultaneously since the dawn of history and the first men, and which still assert themselves in history today' (MECW 5: 43). Human beings must firstly produce the means to satisfy their basic needs, e.g. eating, drinking, housing, clothing; they secondly create new needs, and thirdly, while daily re-creating their own life, they also 'propagate their kind' and create relations between man and woman, parents and children (MECW 5: 41-3); these three 'moments' so far are then fourthly summarized by a surprisingly comprehensive concept of 'production', namely, the 'production of life, both of one's own in labour and of fresh life in procreation', which are in turn connected to different modes of co-operation (MECW 5: 43); fifthly, people also have 'consciousness', which does, however, not manifest itself in the 'pure' form the idealistic philosophers imagined: it was 
from the outset afflicted with the curse of being 'burdened' with matter, which here makes its appearance in the form of agitated layers of air, sounds, in short, of language. Language ... is practical, real consciousness that exists for other men as well ... and .... arises from the need, the necessity of intercourse with other men. ... Consciousness is, therefore, from the very beginning a social product, and remains so as long as men exist. (MECW 5: 43-4)

What is astonishing here is the prescience with which Marx and Engels anticipated some of the insights of later linguistic accounts that describe the material and social character of meanings with the concept of 'discourse' or 'discursive practice'. It is obvious that their line of argument has nothing to do with an 'objectivist fantasy' (Williams) of human life devoid of meaning and language. Nor is it a demonstration that language and consciousness have only a 'secondary' status. Instead of asserting that consciousness does not belong to the real practice of life, they argue that it could only be understood as an integral part of life practices, and therefore as a composite of social relations. As soon as one deals with their core argument, it becomes evident that they criticize the philosophy of consciousness not from the perspective of an underlying dichotomy between (primary) 'life' and (secondary) consciousness, but rather because it severed consciousness from the practical contexts of life in order to demonstrate its nature as primary force.

Where the critics of The German Ideology bring out their heaviest guns, namely the 'naïve' and empiricist epistemology that allegedly underpinned its concept of ideology, the result is ambiguous at best. The criticism catches Marx and Engels red-handed as they fight a hand-to-hand scuffle with their opponents, and thereby move within their opponents' discursive materials, taking up their idealistic discourses of a philosophy of consciousness and polemically turning it against them. This is the case, for example, when they assume that 'life determines consciousness' (MECW 5: 37), or when they famously assert that it is 'not the consciousness of men that determines their existence, but their social existence that determines their consciousness' (MECW 29: 263). It is also undeniable that descriptions of ideology as 'false' or 'inverted consciousness' suggest - similarly to the terms 'echo' and 'reflex' - a concept of ideology as a volatile epiphenomenon, a castle in the air without any materiality and efficiency of its own. But the criticism misses the anti-objectivist and praxis-philosophical thrust of the overall argument in both the Theses on Feuerbach and The German Ideology.

It misses, furthermore, that Marx and Engels were not primarily interested in debunking particular forms of consciousness but rather in explaining them from their societal foundation: the 'inversion' of ideology, its 'standing on its head' was for them an effect of the social division of material and mental labor, which they saw in turn intimately connected with the formation of private property, class and gender antagonisms and the state. It is only because of this underlying social division that 'consciousness can really flatter itself that it is something other than consciousness of existing practice, that it really represents something without representing something real'. Only by means of this division is "consciousness [...] in a position to emancipate itself from the world and to proceed to the formation of "pure" theory, theology, philosophy, morality", which are practiced by specific intellectual groups 'as a profession, that is, as a business' (MECW 5: 45, 379). In this vein, Marx and Engels proposed, for example, to explain the predominance of the 'spirit' in German historiography 'from its connection with the illusion of ideologists in general, e.g. the illusions of the jurists, politicians (including the practical statesmen)', which are themselves to be explained 'from their practical position in life, their job, and the division of labour' (MECW 5: 62). What makes possible and produces this reversal of consciousness is the real detachment of intellectual activities from social production, their growing independence and their privileged position in relation to social labor. This applies, for example, to the emergence of religion as an ideology, which is to be distinguished from the magic and natural mysticism of pre-state societies by the formation of a specialized priesthood that is set free from manual labor. 'The 
first form of ideologists, priests', Marx wrote in a marginal note that in turn illustrated a passage written by Engels: 'Division of labor only becomes truly such from the moment when a division of material and mental labor appears' (MECW 5: 44-5).

It becomes clear from this vantage point that the camera obscura is to be understood not so much as a metaphor for 'false consciousness' but rather for the 'idealistic superstructure' of class societies (MECW 5: 89). The fact that The German Ideology combined here a category that was usually employed for describing a world view or philosophical tradition (namely 'idealistic') and a category for a material and institutional reality ('superstructure') is symptomatic for the transition from a traditional discourse of consciousness to a historical-materialist ideology-theory. ${ }^{2}$ Used in this sense, the attention of ideology-theory should not remain bound to the inner image of the camera obscura but should come in from the side and investigate the material arrangement and the socially unconscious of the discourse of consciousness. As Wolfgang Fritz Haug argued, the detachment of consciousness 'is framed and constituted by the material 'dispositif' [in a Foucauldian sense] of social domination' (Haug, 1984: 24). A similar view was held by Pierre Bourdieu who took The German Ideology's considerations on the divisions of manual and mental labor (as well as of town and countryside) as a starting point from which to develop his concept of social 'field' in the domain of religion (Bourdieu, 1991: 6, 9).

The proposed reading of Marx and Engels can be summarized in the following methodological rule: in order to discover their theoretical paradigm shift, it is important to differentiate between different textual layers, namely on the one hand where they move (usually polemically) within the very discourse formations they are about to criticize and, on the other hand, where they move beyond these discourses and articulate their own methodology. To criticize the shortcomings of their discourse of 'false' or 'inverted' consciousness as well as their simplistic reversals of 'life' and 'consciousness' is certainly justified, all the more as it was exactly these formulae that seemed to justify the usual, indeed objectivist understanding of 'materialism' in Marxism. But as soon as one takes the underlying social arrangement of the division of labor, of class formation, gender antagonism and the emergence of the state into consideration, one can see that Marx and Engels made a decisive shift towards an ideology-theory that conceived of the ideological as a material arrangement in society.

Let us note in passing that this is not an isolated finding, but rather reveals a pervasive tendency characterizing their different usages of ideology. When Marx analyzes in Capital the fetishism of the commodity, of money, and of capital, he is not solely concerned with the mystifications in the brain, but rather with the objective inversions in capitalism, by which exchange value rules over use value, abstract labor over concrete labor, and private capitalist profit rules over people's lives. It is these objective inversions that engender 'socially valid, and therefore [...] objective thought forms', by which people spontaneously perceive their conditions (MECW 35: 87, 542; cf. Marx, 1976: 169, 682). Marx combines here again a term describing consciousness (thought form) and a term referring to 'reality' (objective). As an 'objective thought form', commodity fetishism is both a form of social life in capitalist society and a corresponding form of practice and consciousness. ${ }^{3}$ Marx points out again and again that this 'religion of everyday life' is so deeply anchored in socioeconomic reality that it cannot be unhinged by a critique of 'false consciousness': even when scientifically disproved, its everyday validity and efficacy remain unbroken, since 'the actual agents of production themselves feel completely at home in these estranged and irrational forms of capital-interest, land-rent, labor-wages, for these are precisely the configurations of appearance in which they move, and with which they are daily involved' (Marx, 1981: 969).

The later Engels anchored the concept of ideology in a critical theory of the state. He defined the state as 'the first ideological power over man', followed by the law and the 'higher' ideological powers like religion and philosophy (MECW 26: 392-3). It is obvious that these definitions have 
moved far away from a notion of ideology as 'false consciousness'. As a 'power, having arisen out of society but placing itself above it, and alienating itself more and more from it', the state has become 'the admission that this society has become entangled in an insoluble contradiction with itself, that it has split into irreconcilable opposites which it is powerless to dispel' (MECW 26: 269). According to the Projekt Ideologietheorie, Marx and Engel's reflections on ideology can be 'summarized' by the late Engels' concept of ideological powers: 'Marx and Engels' analyses are focused on the connections between state and ideology, their ideology-critique is oriented towards [...] the withering away of the state' (PIT, 1979: 19).

What is common to the different usages of ideology by Marx and Engels is therefore that they were dealing with structurally anchored societal arrangements. As Fredric Jameson observed, Marx's theory of ideology is not 'one of false consciousness, but rather one of structural limitation and ideological closure' (1981: 52). The 'materiality' of the ideology was certainly not a new discovery of Althusser. Apart from Gramsci, it can already be found in the writings of Marx and Engels, even though mostly implicitly and at times hidden beneath the predominant discourse of consciousness of the time. A second characteristic is that they used ideology as a critical concept, i.e. not every world-view, mode of perception, thinking or feeling is by definition ideological. Rather, the term referred to specific powers and forms, which are part of the reproduction of class societies and can thus be re-appropriated and 'horizontalized' in a classless society without structures of domination. The same heuristic perspective underlies Marx's critique of fetishism: the 'objective thought forms' of the commodity, wage, and capital fetishism are to be overcome by 'an association of free men, working with the means of production held in common' (Marx, 1976: 171).

It was therefore a problematic development that both the 'official Marxism' of the Second International and the 'Marxism-Leninism' of the Third International carried out a 'neutralization' of the concept of ideology (namely, as an ideational form of expression of class interests in general), which all but eliminated Marx and Engels' ideology-critique in its different varieties. Only few Marxist theorists took seriously that the Communist Manifesto's goal of 'an association in which the free development of each is the condition for the free development of all' (MECW 6: 506) implied for Marx and Engels the perspective of a society not only without antagonistic classes but also without submission to ideologies in the sense of 'superior' ideological powers connected to state domination. One of the few was György Lukács, who took Marx's critique of commodity fetishism as the cornerstone of his overall theory of reification. Whereas Marx had used the concept to describe specific economic thought-forms, Lukács generalized its meaning so that it meant a 'universal category of society as a whole', seamlessly penetrating all levels of social consciousness (Lukács, 1971: 86, 93). This ideology-critical paradigm was taken up and developed further by the early Frankfurt School around Horkheimer and Adorno.

Another line is represented by Antonio Labriola who, in 1896, described what he called 'critical communism' as being critical of any 'ideology', including a communist one. According to him, Marxist theory is opposed to 'ideologies of every sort'; it is 'the clear and definite negation of all ideology' (Labriola, 1966: 73-4, 98, 123). It is in particular Labriola who leads us to an ideologycritical dimension in Gramsci's approach, which has been overlooked for a long time.

\section{Gramsci's Combination of Ideology-Critique and Theory of Hegemony}

It is a widely held opinion that Gramsci had left behind Marx and Engels' ideology-critique and replaced it with a 'neutral' concept of ideology. Stuart Hall summarized Gramsci's concept of ideology as 'the mental frameworks - the languages, the concepts, categories, imagery of thought, and the systems of representation - which different classes and social groups deploy' (Hall, 1996: 26). 
Similarly, Peter Thomas concluded that in Gramsci's 'most significant formulation of this concept ... ideology is conceived in a neutral sense, as the form in which humans know a world wracked by the "real" contradictions of class struggle' (Thomas, 2009: 281). One could, however, object right away that forms of thought 'wracked' by class contradictions are not a good example for a 'neutral' concept of ideology, since Marx and Engels saw class antagonisms (and their ideological representations) as a transitory phenomenon in history, which is to be overcome in a classless society, or, as Gramsci reformulated, will be 'subsumed into regulated society' (1971: 263). The relationship between Gramsci's theory of hegemony and Marx and Engels' ideology-critique therefore needs to be disentangled more carefully. This is no easy task. Whereas his opposition to the treatment of ideology as immediate expression of the economy, as illusion and as mere appearance, was pervasive, the use of the term itself oscillated between different and partly opposite meanings.

Gramsci, who did not know The German Ideology (published in 1932) and did not show much interest in Marx's critique of fetishism, started out his work on the Prison Notebooks with the translation of two texts, namely of Marx's Theses on Feuerbach and of his Preface to the Critique of Political Economy of 1859. The translation of this second text already displayed a particular interest in the specific reality of the ideological: where the original text spoke of the 'ideological forms in which men become conscious of this conflict and fight it out', Gramsci translated 'in which' (German 'worin') as 'on which terrain [nel cui terreno]'. ${ }^{4}$ The fact that he added the term 'terrain', which was not in the German text, suggests that he intended to avert the common misunderstanding of mere forms of consciousness from the outset. The 'ideological terrain', which from now on will continually accompany the treatment of ideologies, expressed an understanding that these 'are anything but illusions and appearance' but, rather, an 'objective and effective reality', the terrain of the 'superstructures'. ${ }^{5}$ Far from being a 'marché de dupes' (fool's bargain), a game of illusions and tricks, ideology is to be understood as as the 'entire ensemble of superstructures' (1975: 164).

Let us pause here a moment and clarify that this shift has so far nothing to do with the substitution of a critical concept of ideology by a 'neutral' one. We are rather dealing with a clear departure from any notion of ideology that is restricted to 'consciousness' (be it 'false' or understood in a 'neutral' sense) or to a 'mental framework' in general (Hall). Instead, Gramsci focuses on what later ideology-theorists described as the 'materiality' of the ideological, its 'trenches' in civil society, 'hegemonic apparatuses', 'organic' or 'traditional' intellectuals, complex and multiple power relations, etc. This materialistic shift does of course not indicate a break with Marx and Engels' approach, which targeted, as we have seen, not just forms of consciousness but real 'ideological powers', apparatuses, 'ideological forms', 'ideological estates' and 'conceptive ideologists' that can in turn be seen as part of what Gramsci called the 'integral state', consisting of 'political society' and 'civil society', 'hegemony protected by the armour of coercion' (1971: 263).

What is different, however, is that Gramsci also used the concept of ideology positively, predominantly in cases when a philosophy went beyond the limited bounds of the intellectuals and was diffused into the great masses. In this positive usage (which is again not 'neutral') ideology signified the 'mass element of any philosophical conception, its conforming "moral will" and "norm of conduct". 6 The terminology became somewhat blurred by the fact that Gramsci described the same connection between world view and conforming 'norm of conduct' with Croce's wide notion of 'religion', as well as with terms like 'faith', 'politics', 'culture', 'ethics' or 'intellectual and moral reform'. When philosophies become 'ideologies', they assume the 'fanatical granite compactness' of the 'beliefs of the people', which take on the same energy as 'material forces' (1971: 404) - a formulation which refers, of course, to the famous quote of the young Marx that theory becomes a 'material power as soon as it has gripped the masses' (MECW 3: 182-3). Gramsci explicitly addressed a polysemy of the 
concept of ideology, which could be applied to both 'arbitrary elucubrations of particular individuals' and the 'necessary superstructure of a particular structure'. Consequently, one must distinguish between 'historically organic ideologies, which ... are necessary to a given structure, and ideologies that are arbitrary, rationalistic, or "willed." Whereas the latter only created individual 'movements' and polemics, the former "'organise" human masses and create the terrain on which men move, acquire consciousness of their position, struggle' (1971: 376-7).

It seems at first glance as if it is precisely by this positive and 'organic' usage that Gramsci departs from Marx and Engels' critical concept of ideology. To stop here would, however, be misleading. Gramsci's terminology in regard to ideology is heterogeneous and contains both positive and critical usages. The latter were mostly due to the influence of Antonio Labriola, from whom Gramsci also adopted the term 'philosophy of praxis'. It is therefore no coincidence that Gramsci's critical concept of ideology was particularly clear when he used the term in opposition to the concept of the philosophy of praxis, which 'freed itself (or is trying to free itself) from every one-sided and fanatical ideological element' (1975: $Q$ 11, $\$ 62,1487)$. Similar to Labriola, who anticipated the danger that the philosophy of praxis becomes again a 'new inverted ideology', in particular when people 'unfamiliar with the difficulties of historic research' transform it into 'a new philosophy of systematic history', i.e. 'history conceived as schemes or tendencies or designs (1966: 126-7), Gramsci was well aware that Marxism was not exempt from slipping back into an 'ideology in the worst sense of the word, that is to say a dogmatic system of eternal and absolute truths' (Gramsci, 1971: 406-7). He observed such a relapse into ideology not only when it occurred in an elaborate philosophical form but also on the level of popular common sense: it was the 'subaltern' character of certain social strata which necessarily created a 'direct ideological "aroma" emanating from the philosophy of praxis', namely in the form of 'mechanical determinism': 'I have been defeated for the moment, but the tide of history is working for me in the long term'. Such a determinism had the historical merit of becoming 'a tremendous force of moral resistance, of cohesion and of patient and obstinate perseverance', but at the same time it functioned as a 'substitute for the Predestination or Providence of confessional religions', which meant that the 'activity of the will' was present 'only implicitly, and in a veiled and, as it were, shamefaced manner', lacking 'critical unity'. Such fatalism was the 'clothing worn by real and active will when in a weak position'. Determinism had intrinsic strength as a 'naive philosophy of the mass' and 'religion of the subaltern', but as soon as it was elevated by intellectuals to a thought out philosophy it became a cause of passivity and 'idiotic self-sufficiency' (1971: 336-7).

It was against the backdrop of these continuous tendencies of re-ideologization that Gramsci emphasized the ideology-critical perspective of the philosophy of praxis: whereas other ideologies aim at 'reconciling opposing and contradictory interests', the philosophy of praxis is the 'very theory of these contradictions'. Instead of functioning as an 'instrument of government of the dominant groups in order to gain the consent of and exercise hegemony, it is the expression of these subaltern classes who want to educate themselves in the art of government and who have an interest in knowing all truths, even the unpleasant ones'. For this they needed to dismantle not only the deceptions of the upper class but also 'and - even more - their own' (Gramsci, 1995: 395-6). Marxist philosophy could realize its ideology-critical potency by its capacity to think through its own historical conditions of existence: not only does the philosophy of praxis 'claim to explain ... the entire past, but also to explain ... itself historically'. Gramsci called this a 'maximum "historicism", the total liberation from any abstract "ideologism", the beginning of a new civilization' (Gramsci, 1975: $Q$ 16, §9, 1864).

We can see now that the widespread scholarly habit to single out a 'neutral' concept of ideology in Gramsci flattens out his contradictory usage in a way that the overall ideology-critical perspective drops out of sight. Such a one-sidedness dissimulates that Gramsci's dealings with 'common 
sense', 'passive revolution', 'religion', 'Fordism', etc., are examples of a vigorous and differentiated ideology-critique. Let us take as a case in point his distinction between 'common sense' and 'good sense' and their different relationships to ideology and philosophy:

"Philosophy is criticism and the superseding of religion and "common sense" [senso comune]. In this sense it coincides with "good sense" [buon senso], which is opposed to "common sense"' (Gramsci, 1971: 326; cf. Gramsci, 1975: $Q$ 11, §12, 1378).

Whereas Althusser's theory of 'ideology in general' presents a homogeneous top-down model of eternal submission, Gramsci tries to grasp a heterogeneous ensemble of four dimensions: 1) a senso comune, incoherent and disjointed, 'strangely composite' of different historical layers and opposite social perspectives; 2) the weight of ideologies (here religion) upon and within common sense; 3) on the other hand buon senso, which he defines elsewhere as a 'healthy nucleus' of common sense, characterized by a sense of 'experimentalism' and open to new experiences; ${ }^{7}$ and finally 4) a philosophy of praxis that has the task to 'coincide' with buon senso, taking it as a stronghold from which it works to render common sense more coherent. ${ }^{8}$

Gramsci's critique of common sense is thus an ideology-critique in the sense that it tries to push back the overwhelming impact of ideologies on common sense and to strengthen the inherent potentials of realistic experience and capacity to act. Contrary to Horkheimer and Adorno, who treat common sense as if it were merely a passive effect of a manipulative 'culture industry', Gramsci's critique is not a frontal attack, but rather manifests itself as a 'a criticism of "common sense", basing itself, ... however, on common sense in order to demonstrate that "everyone" is a philosopher and that it is ... a question of ... renovating and making "critical" an already existing activity' (Gramsci, 1971: 330-1). The assertion that 'everyone' is a philosopher and intellectual indicates the fundamental anti-elitist and democratic perspective of his critical intervention. The apparently paradoxical notion of a critique of common sense based on common sense and its inherent, 'already existing' intellectual activity contains a significant paradigm shift from a totalizing and ultimately elitist ideology-critique to a dialectical and constructive one.

Gramsci explicitly claims the notion of ideology-critique and defines it in a way that breaks with the paradigm of a mere critique of 'consciousness': in the framework of a philosophy of praxis, the critique of ideologies 'involves the ensemble of the superstructures' in order to induce a 'process of distinction and change in the relative weight' of the ideologies so that the 'old collective will disaggregates into its contradictory elements'. ${ }^{9}$ These thoughts were later elaborated in terms of discourse theory as 'disarticulation' and 're-articulation' of ideological formations, by means of which ideology-critique could become effective as an 'interruptive discourse' that intervenes in the ideological block of the opponent in order to decompose it, to reshape it and build effective elements into a new order. ${ }^{10}$

What is therefore remarkable is that Gramsci did not follow the general trend of contemporary Marxism and altogether abandon the critical concept of ideology of Marx and Engels, but combined elements of it - via Labriola - with his new concept of hegemony. 'Ideological' are those mechanisms that keep the popular classes in submission to 'foreign hegemonies', ${ }^{11}$ a submission which impedes the passage from 'subalternity' to an ethico-political level. If one resists the temptation to rashly homogenize Gramsci's contradictory usages of ideology and instead maintains the dialectical tension between them, one can see that they constitute a particular theoretical strength: they indicate that Gramsci tries to do both - on the one hand understand, long before Althusser, the materiality of the ideological, its existence in apparatuses and practices, its efficacy, and on the other hand maintain that a philosophy of praxis has to operate as a permanent ideology-critique, not least in relation to one's own ideologies. Every Marxist political project has to deal with the contradiction that 1) 
it must intervene into the ideological forms of the existing class society and is thereby necessarily co-determined by them, forced to become an 'ideology' of its own; and therefore 2) needs a strong ideology-critical philosophy of praxis that helps to think through what it is doing and to historicize its own ideological involvements. To obscure or to neglect a theoretical understanding of this contradiction only leads to a passive dialectics that produces endless splits and defeats.

There remains, however, an important gap in Gramsci's combination of ideology-critique and theory of hegemony, namely, the absence of Marx's critique of fetishism. Gramsci's lack of interest is astonishing, as the 'objective thought forms' emerging from commodity, wage, and capital fetishism constitute a dimension of common sense that is relevant with regards to understanding its contradictory composition. In order to overcome this one-sidedness, it would be worthwhile to combine Gramsci's approach with Henri Lefebvre's approach in a Critique of Everyday Life (2008), which started from Marx’s analysis of alienation and fetishism.

\section{Beyond Althusser: The Project of a Critical-Structural Theory of Ideology}

So far, our reading goes deliberately against the grain of a predominant tendency in secondary literature, which places Marx/Engels' and Gramsci's concepts of ideology on opposite poles of the spectrum. The interpretation misses that both approaches gained their specific strength by a particular combination of a critical concept and a structural concept of ideology that focuses on the underlying societal arrangements, in which specific modes of consciousness and attitudes are engendered. The fact that these combinations were all but overlooked is to a large part due to the influence of Althusser, who defined the notion of 'ideology-theory' in a way that it lost its connection with the tradition of ideology-critique. It is in this respect that I turn to Althusser's approach.

Notwithstanding his polemics against Gramsci's 'historicism' and his attempt to reduce Gramsci's theory to unsystematic 'intuitions' and fragmentary notes, Althusser based his own ideology-theory on essential aspects of Gramsci's analyses of civil society and hegemonic apparatuses. As he himself indicated, his distinction between repressive and ideological state apparatuses (ISAs) is formed following the model of Gramsci's differentiation of 'political society' and 'civil society', coercion and hegemony (Althusser, 2001: $95 \mathrm{fn} 7$ ). The treatment of the ideological apparatuses as state apparatuses would not be comprehensible without Gramsci's enlargement of a traditional narrow concept of the state to the wider concept of the 'integral state'. Both Gramsci's 'integral state' and Althusser's ISAs include those institutions and associations that are usually considered to be 'private'. But whereas Gramsci was primarily interested in the possibilities of how subaltern classes develop the hegemonic capacities to occupy the different levels of the superstructures, Althusser's main attention was directed to the ways an ideological subjection under the bourgeois state is accomplished by the ISAs. The two perspectives are of course not mutually exclusive, but could complement each other in a productive way. New in comparison to Gramsci are particularly the concepts of the subject and the voluntary subjection [assujettissement] that Althusser developed on the basis of the psychoanalysis of Jacques Lacan. Psychoanalytical categories enabled him to understand the ideological as an unconscious, 'lived' relationship and to illustrate the dynamic and active character of ideological subjugation. At the same time, the integration of Lacanian psychoanalysis exposed Althusserian ideology-theory to the tension between the historically specific ISAs concept and an unhistorically conceived 'ideology in general' - a contradiction which led to divided receptions and finally contributed to the disintegration of the Althusser School.

I will not discuss here the many productive insights of Althusser's ideology-theory, ${ }^{12}$ but focus on what I consider to be a fundamental loss: Due to his understanding of Marxism as a 'theoretical antihumanism', Althusser rejected the notions of alienation and fetishism and turned against Marx' 
and Engels' critical concept of ideology, which he wrongly identified with the paradigm of 'false consciousness'. He thereby dropped the ideology-critical perspective, which was also a crucial component of Gramsci's theory of hegemony. 'Ideology in general' became for him an 'organic part of every social totality'; it was 'eternal, exactly like the unconscious', i.e. 'omnipresent, transhistorical and therefore immutable in form', so that the human being was conceived of as an 'ideological animal by nature'. ${ }^{13}$ In this sense Althusser moved within the 'neutral' concept of ideology of Marxism-Leninism, even though it was now legitimated by a psychoanalytic point of view. Based on Lacan's concept of the 'imaginary', the 'misrecognitions', which Marx had located in the alienated structures of class antagonistic societies, were once again relocated into the individual and comprehended as an unhistorical-anthropological essence. Instead of developing the 'celestialised forms' of the ideological out of the 'actual relations of life', which Marx called the 'only materialist and therefore scientific method' ${ }^{14}$, Althusser handed over all human action and thought to an overwhelming structure of alienation and misconception that is based on the premise of a primary 'un-societal foundational structure' of the individual. Concrete analysis of the respective conditions of action were thus replaced with a reductionist procedure: 'in the night of the subjecteffect all practices turn grey'. ${ }^{15}$

Similar to his predecessors of the Second and Third International, Althusser thus eliminated again the ideology-critical perspective of Marx and Engels. By doing this, he contributed to what Juha Koivisto and Veikko Pietilä described as the main 'dilemma' of the research on ideology, namely a polarization between ideology-critical approaches fixated on the critique of consciousness, and ideology-theories that break with the critique of consciousness but instead reintroduce a 'neutral' concept of ideology (Koivisto and Pietilä, 1993: 238). The former focus on the critique of inverted and reified forms of social consciousness (Lukács) or of 'instrumental reason' and 'identitarian thought' (Horkheimer/Adorno), but have major difficulties taking into account the discursive struggles in the hegemonic apparatuses of civil society; the latter distance themselves from the totalizing tendencies of the Lukács-paradigm, but by their re-introduction of a 'neutral' concept of ideology lose the ideology-critical dimension of Marx and Engels and thereby the analytical sharpness of the concept altogether. What Koivisto and Pietilä found widely missing so far was a 'critical-structural conception of ideology' that accounts for both the material and alienated existence of ideology and is able to connect the two strands in an organic way (Koivisto and Pietilä, 1993: 243).

It was first and foremost the Projekt Ideologietheorie (PIT) that developed such a criticalstructural conception of ideology. Following Engels's concept of 'ideological powers', the PIT distinguishes between the individual ideologies and the 'ideological', which it comprehends not primarily as an edifice of thought and consciousness but rather as an institutional framework determining human practices, thought-forms and attitudes. The ideological is connected with a specific organizational form of class societies reproduced by the state and thus designates the functioning and efficacy of an 'alienated socialisation from above' ${ }^{16}$

At the same time, the structural concept of the ideological remains ideology-critical in the sense that it deals with the functioning of ideological powers, practices, and discourses from the perspective of their 'withering away' in a society without class, state and patriarchal domination. Compared to Althusser's 'ideology in general', the concept of ideology is more specific, which in turn makes it possible to distinguish between different dimensions of socialization apart from the ideological dimension, for example: 'horizontal' forms, by which people try to organize their lives together without the imposition of superordinated ideological entities; utopian impulses, which exceed the ideological form; or dimensions of the cultural, in which individuals and groups arrange their activities in a sensuously enjoyable way and 'practice what appears to them to be worth living'. It is important to bear in mind that these are analytical distinctions, which in empirical reality intersect and permeate each other. As Boltanski and Chiapello have shown, many of the 
counter-cultural articulations of the ' 68 movement in France were successfully co-opted by a neoliberal management ideology and marketed as a new lifestyle (2007: 197ff., 326, 461, 498). And conversely, certain community-oriented functions which are represented and preserved in ideologies can be successfully reclaimed by oppositional social movements and redirected toward their own capacity to act.

Althusser's ideology-theory conceptualized the construction of ideological subjects and subjectivities too monologically from the top down. In his model of interpellation, the small subjects interpellated by the big Subject can do no more than 'turn around', recognize themselves in the call and affirm it with 'yes'. ${ }^{17}$ Many theorists criticized this model for its functionalism and its disregard for contradictions and different forms of resistance and subversion. According to Judith Butler, the law might not only be refused, but it might also 'be ruptured, forced into a rearticulation that calls into question the monotheistic force of its own unilateral operation', so that there is always a 'slippage' between the discursive command and the effects, a 'constitutive failure of the performative', which might open possibilities for resignifying the terms (Butler, 1993: 122, 124). Žižek argues that the interpellations would not be effective in subjecting the subjects without an underlying 'ideological jouis-sense, enjoyment-in-sense' (1989: 43-4). Stuart Hall contrasted Althusser's model with a more flexible and dialectical one, which differentiates between the coding of an ideological message and its active decoding by the interpellated subject. With this he can distinguish between three different types of responses: a 'dominant-hegemonic' model, according to which the decoding takes place within the dominant code; a 'negotiated code', in which the dominant position is accepted only on a general level and redefined independently with regard to the local conditions; and finally an 'oppositional code', by which the addressees interpret the message in a 'globally contrary way' (Hall, 1993: 517). It is obvious that Althusser's model of interpellation only covers Hall's first variety, and even in this case, the interpellated subjects would only subjugate themselves 'voluntarily', if they recognized something 'of their own' in the interpellation.

This 'of their own' is, according to the interpretation of the Projekt Ideologietheorie, a dimension of the 'common' (Gemeinwesen) that is represented in ideologies, however displaced and alienated. ${ }^{18}$ There is a dialectic of the ideological, according to which each ideology that appeals to the broader masses must also contain elements of the common - for example, plebeian and countercultural motifs. In a similar vein, Fredric Jameson has argued that ideologies 'must necessarily involve a complex strategy of rhetoric persuasion, in which substantial incentives are offered for ideological adherence', which means that the 'effectively ideological' also contains utopian impulses referring to a solidarity with other members of the respective class or group (1991: 285-90). This is by no means a peculiarity of 'progressive' tendencies, but also applies, for instance, to right-wing populist and fascist ideologies, whose success, as Ernst Bloch had already shown in 1933, can be explained, among others things, by their 'thefts from the commune' (Bloch, 1990: 64).

The Projekt Ideologietheorie has conceptualized this inner contradictoriness with two concepts: first, with Freud's concept of 'compromise formation', through which opposite forces (e.g. the super-ego and the repressed wishes of the id) are condensed into a neurotic symptom; second, with the concept of an 'antagonistic reclamation of the Gemeinwesen ' (of the community, or of the common), by which the same ideological instances and values are interpreted and claimed in an opposite perspective. ${ }^{19}$ Different classes, genders, and generations often interpret very differently, what God's Will is, what justice means, what morality proclaims, and what aesthetics and taste define to be 'beautiful' or 'ugly'.

As soon as one accounts for the contradictory composition and antagonistic reclamation of the ideological, the notion of ideology-critique takes on a new, constructive assignment, namely to pick up the 'horizontal' functions of the common represented in the ideological, to claim them and 
to fetch them back for the development of a capacity to act in solidarity. This means, for example, that a critique of religion informed by ideology theory should not try to prove again and again that religion as such is an 'inverted consciousness' or 'opium of the people'. Its analytical task is rather to decipher the social antagonisms and struggles in the field of religion and to set free its emancipatory impulses (cf. Rehmann, 2011: 151-2).

A critical ideology theory has of course to be continuously fine-tuned to the concrete transformations and conjunctures of high-tech capitalism. In order to conceptualize the importance of repression and surveillance, which formed already before the attacks of September 11, 2001 and were then more and more enlarged during the 'war on terror', Stephen Gill has coined the term 'disciplinary neoliberalism'. It describes a constellation in which the Fordist modes of regulation that were based upon a class compromise with some upper echelons of the working class, traditionally called the 'labor aristocracy', have been displaced by strategies of 'supremacy' that are primarily based upon the depoliticization and fragmentation of oppositional forces. ${ }^{20}$ This does not mean, however, that neoliberal ideologies have no popular impact any more. They still function like a 'compromise-formation', which combines the promises of individual emancipation and self-activation with the requirements of the 'market'. Neoliberalism presents itself as liberating agency from a patronizing state-bureaucracy; it mobilizes its subjects by permanently interpellating them to be active and creative, to show initiative and to believe optimistically in the success of their efforts. At the same time it calls upon the subjects to submit to the fateful order of the market that regularly and increasingly fails and frustrates the efforts of the many. An effective ideology critique should focus on this inner contradiction and turn the impulses of selfconduct against the bourgeois forms of 'possessive individualism' (McPherson). ${ }^{21}$

One of the main (and most difficult) questions is whether or to what extent neoliberal high-tech capitalism has lost or is going to lose its ideological capacities of subject-mobilization and how the left could respond to such a hegemonic crisis by developing and promoting an appealing democratic-socialist alternative. Ideological interpellations need of course a sufficient economic substratum to be effective in the long run. To the extent that this substratum is shrinking in a period of economic crisis, neoliberalism's hegemonic capacity is at risk of being eroded. It cannot, however, be determined beforehand for how long the elites and their ideologues will succeed in shifting the blame onto the policies of former governments, onto the 'greed' of the bankers, to trade unions, immigrants and other enemy-images, or at what point the fundamental contradiction between capitalism and democracy becomes visible and opens the way to new anti-capitalist movements and alliances.

In the academia and in particular in the humanities, we have experienced a long period of postmodernist hegemony, during which both traditions of ideology-critique and ideology-theory were marginalized in the academia as well as in various social movements. The substitution of ideology by discourse and power actually had the consequence that the social was reduced to the symbolic and the material to the efficacy of 'norms', so that the profane reality of capitalism was all but obfuscated. This capitalist reality needs to be brought back to center stage. Its different forms of alienation, its production of mass impoverishment, its dismantling of democracy and build-up of repressive apparatuses, the interlocking of class rule and patriarchal gender relations, and the current crisis of neoliberal hegemony are in dire need of what the young Marx called a 'ruthless criticism' (rücksichtslose Kritik), 'in the sense of not being afraid of the results it arrives at and ... just as little afraid of conflict with the powers that be' (MECW 3: 142). After having learned our postmodern lessons in the domains of epistemology and methodology, we need to again take up the project of an ideology-critique that operates with a theory of the ideological as a 'conceptual hinterland' (Haug, 1993: 21). 


\section{Funding}

This research received no specific grant from any funding agency in the public, commercial, or not-for-profit sectors.

\section{Notes}

1. For example, MECW 3: 175; MECW 5: 27ff.; MECW 35: 19.

2. Marx would later, in Theories of Surplus Value, employ the category of 'superstructure of ideological strata' (Marx, 1969-71 [Part 1]: 287).

3. Žižek's assumption that the 'essential feature of commodity fetishism [...] consists of a certain misrecognition which concerns the relation between a structures network and one of its elements' (1989: 23-4) is therefore misleading.

4. Gramsci (1975: 2359); cf. Marx (MECW 29: 263); in the original German version: 'ideologischen Formen, worin sich die Menschen dieses Konflikts bewusst werden und ihn ausfechten' (MEW 13: 9).

5. Gramsci (1975: $Q 4$, §15, 436-37; $Q$ 10.II, §41.XII, 1319; $Q$ 11, §64, 1492; $Q 13$, §18, 1595-6).

6. Gramsci (1975: $Q$ 10.II, §41.i, 1292; $Q$ 10.II, §2, 1242; $Q$ 10.II, §31, 1269).

7. Cf. Gramsci (1971: 328, 348; 1975: $Q$ 10.II, § 48; $Q$ 11, § 56; $Q 16, \S 21 ; Q 12, \S 12,1378)$.

8. Cf. Gramsci (1975: $Q 15, \S 22,1780)$.

9. Gramsci (1971: 195; 1975: $Q 8$, §195; $Q$ 10.II, §41.XII; 1995: 396).

10. Cf. Hall (1988: 56); PIT (2007: 57-8).

11. Gramsci (1975: $Q 6, \S 38,713)$.

12. Cf. Rehmann (2013: 147-78, 285-6).

13. Althusser (1979: 232; 2001: 109, 116).

14. Marx (MECW 35: 374); cf. Marx (1976: 494, fn 4; transl. modified).

15. PIT (1979: 126). The PIT criticized that Althusser's concept of 'ideology in general' was caught in a problematic psychoanalytic opposition between a 'needy individual' and a necessarily 'repressive society' - a dichotomy, in which the formation of self-determined capacities to act could not be conceptualized (PIT, 1979: 121ff.). Cf. Rehmann (2013: 165-73).

16. Cf. Haug (1987: 60-62, 68); Rehmann (2013: 241-8)

17. The big subject GOD calls the small subject Moses by his name, to which Moses responds 'It's really I!' (Althusser, 2001: 121).

18. PIT, 2007: 108. According to Engels, 'Gemeinwesen' (literally: 'common-being') 'is a good old German word that can very well do service for the French 'Commune' (letter to Bebel, 18 and 28 March 1875, in MECW 45: 64). As Hardt and Negri point out in Commonwealth, the common is not only the common wealth of nature, e.g. air, water, fruits of the soil, but also the results of social production (Hardt and Negri, 2009: VIII).

19. Cf. Haug (1987: 71-2, 94); Rehmann (2013: 254-61).

20. Cf. Bakker and Gill (2003: 60, 65, 116ff.).

21. The Foucauldian 'governmentality studies' focused on the neoliberal rhetoric of self-conduct and the promises of self-activation, but neglected their strict subordination to the market-order and thus missed the inner contradiction of neoliberalism (cf. the critique in Rehmann, 2013: 301 and following).

\section{References}

Althusser L (1979) For Marx, trans. Brewster B. London: Verso.

Althusser L (1994) Écrits philosophiques et politiques, Vol. I, ed. Matheron F. Paris: Stock/IMEC.

Althusser L (2001) Ideology and ideological state apparatuses: Notes towards an investigation. In: Lenin and Philosophy and other Essays, trans. Brewster B. New York: Monthly Review Press, 85-126.

Bakker I and Gill S (2003) Power and Resistance in the New World Order. London: Palgrave Macmillan. Bloch E (1990) Heritage of Our Times, trans. Plaice N and Plaice S. Berkeley, CA: University of California Press. Boltanski L and Chiapello E (2005): The New Spirit of Capitalism, transl. Elliot G. London: Verso. Bourdieu P (1991) Genesis and structure of the religious field. Comparative Social Research 13(1): 1-44. 
Butler J (1993) Bodies that Matter. New York: Routledge.

Eagleton T (1991) Ideology: An Introduction. London: Verso.

Gramsci A (1971) Selections from the Prison Notebooks of Antonio Gramsci, ed. and trans. Hoare Q and Smith GN. New York: International Publishers.

Gramsci A (1975) Quaderni del carcere, 4 vol. critical edition, ed. Gerratana V. Torino: Einaudi.

Gramsci A (1995) Further Selections from the Prison Notebooks, ed. and trans. Boothman D. London: Lawrence \& Wishart.

Hall S (1988) The toad in the garden: Thatcherism among the theorists. In: Nelson C and Grossberg L (eds) Marxism and the Interpretation of Culture. London: University of Illinois Press, 35-57.

Hall S (1993) Encoding, decoding. In: During S (ed.) The Cultural Studies Reader. London: Routledge, 507-517.

Hall S (1996) Critical Dialogues in Cultural Studies, ed. Morley D and Chen K-H. London: Routledge.

Hardt M and Negri A (2009) Commonwealth. Cambridge, MA: Harvard University Press.

Haug WF (1984) Die Camera obscura des Bewusstseins. Zur Kritik der Subjekt/Objekt-Artikulation im Marxismus. In: Projekt Ideologietheorie (PIT), Die Camera obscura der Ideologie. Philosophie, Ökonomie, Wissenschaft, ed. Hall S, Haug WF and Pietilä V. Berlin/West: Argument-Verlag, 9-95.

Haug WF (1987) Commodity Aesthetics, Ideology \& Culture. New York: International General.

Haug WF (1993) Elemente einer Theorie des Ideologischen. Hamburg: Argument-Verlag.

Jameson F (1981) The Political Unconscious: Narrative as a Socially Symbolic Act. Ithaca, NY: Cornell University Press.

Koivisto J and Pietilä V (1993) Der umstrittene Ideologiebegriff. W.F. Haugs Theorie des Ideologischen im Vergleich: In: HaugWF, Elemente einer Theorie des Ideologischen. Hamburg: Argument-Verlag, 233-246.

Labriola A (1966 [1896]) Essays on the Materialist Conception of History, trans. Kerr CH. New York: Monthly Review Press.

Lefebvre H (2008) Critique of Everyday Life, trans. Moore J and Elliot G. London: Verso.

Lukács G (1971) History and Class Consciousness, trans. Livingstone R. Cambridge, MA: MIT Press.

Marx K (1969-71) Theories of Surplus-Value, Parts I-III, trans. Burns E, ed. Ryazanskaya SW. Moscow: Progress Publishers.

Marx K (1976) Capital: A Critique of Political Economy, Vol. I, trans. Fowkes B. London: Penguin Books.

Marx K (1981) Capital: A Critique of Political Economy, Vol. III, trans. Fernbach D. London: Penguin Books.

Marx K and Engels F (1957-) Marx-Engels-Werke, 42 Vols, ed. Institut für Marxismus-Leninismus beim ZK der SED. Berlin/GDR: Dietz Verlag (quoted as MEW).

Marx K and Engels F (1975-2005) Marx Engels Collected Works. London: Lawrence \& Wishart (quoted as MECW).

Projekt Ideologietheorie (PIT) (1979) Theorien über Ideologie. Berlin/West: Argument-Verlag.

Projekt Ideologietheorie (PIT) (1984) Die Camera obscura der Ideologie. Philosophie, Ökonomie, Wissenschaft, ed. Hall S, Haug WF and Pietilä V. Berlin/West: Argument-Verlag.

Projekt Ideologietheorie (PIT) (2007) Faschismus und Ideologie, new edition, ed. Weber K. Hamburg: Argument-Verlag.

Rehmann J (2011) Can Marx's critique of religion be freed from its fetters? Rethinking Marxism 23(1): 144-153.

Rehmann J (2013) Theories of Ideology: The Powers of Alienation and Subjection. Leiden: Brill.

Thomas PD (2009) The Gramscian Moment: Philosophy, Hegemony and Marxism. Leiden: Brill.

Williams R (1977) Marxism and Literature. Oxford: Oxford University Press.

Žižek S (1989) The Sublime Object of Ideology. London: Verso. 